\title{
Anotações sobre a imagem mestiça num quadro de Rivera*
}

*Este trabalho faz parte do projeto de pesquisa que venho desenvolvendo com bolsa de produtividade concedida pelo CNPq.

Eduardo Peñuela Cañizal Escola de Comunicações e Artes/USP 


\section{Resumo}

Partindo de imagens de um quadro de Rivera, o autor deste artigo lida com algumas propriedades da imagem mestiça para caracterizar o poder de coexistência desse tipo de configuração e destacar aspectos de sua carga poética.

\section{Palavras-chave}

imagens ameríndias, pintura, metáfora visual, poética

\section{Abstract}

Rivera's painting had an enormous influence on the development of Amerindian images. Analysing the structure of a special type in a canvas of the Mexican painter, the author of this article introduces a shift away from rhetorical research into the life of pictorial configurations.

\section{Key words}

amerindian images, painting, visual metaphor, poetics 
$\bigwedge \begin{aligned} & \text { imagem mestiça, enquanto condensação de iconografias } \\ & \text { que possibilitam a coexistência de temporalidades dife- } \\ & \text { rentes; faz parte desse paradigma em que teóricos de }\end{aligned}$ diversas tendências têm procurado ordenar as características do hibridismo e do sincretismo. Convém, no entanto, lidar com o pressuposto de que tal tipo de imagem possui particularidades que a diferenciam. Não se trata de trabalhar com a hipótese de que a incerteza em relação ao sentido e ao valor da modernidade também deriva, como diz Canclini (1997), dos cruzamentos culturais em que tradição e modernidade se misturam. Nem mesmo de encaixar as propriedades das imagens mestiças no modelo de sincretismo criado por semioticistas que intentam explicar os atos comunicativos resultantes da integração de várias linguagens no plano da manifestação de um texto heterogêneo, caso da ópera ou do cinema, por exemplo.

Sem me opor, entretanto, ao hibridismo cultural estudado por Canclini ou ao entendimento da instância da enunciação como o lugar de uma indistinção original do eu-aqui-agora (Greimas/ Courtès,1979), meu propósito é modesto e se restringe a comentar alguns dos traços que particularizam a imagem mestiça quando temos em vista as relações que ela mantém com os fenômenos dialógicos e cronotópicos entendidos à maneira de Bahktin (Zavala, 1991). Obviamente, não posso ignorar que, no âmbito dos textos visuais, a dimensão plástica e o sistema semi-simbólico (Floch, 1985) deixam sua marca tanto no plano da expressão quanto no plano do conteúdo das imagens mestiças. Mas, por outro lado, tendo tão somente a pretensão de apontar para ocorrências muito específicas, meu compromisso, nesta ocasião, não é o de delinear, de modo sistemático, os esquemas que, na acepção kantiana, balizam o conjunto de propriedades em que se integram as características de uma ima- 
gem mestiça. Em razão disso, minha aspiração não irá além de umas observações inspiradas, de um lado, em leituras ainda bastante desordenadas e, de outro, em vivências muito particulares.

Duas obras constituem a fonte básica de referência destas anotações. O livro que com o título de La Pensée métisse publicou Serge Gruzinski (1999) e o catálogo Diego Rivera. Arte y Revolución, editado pelo Instituto Nacional de Bellas Artes, do México, em 2000. Do primeiro, sem me deter na questão relativa ao papel que o século XV ibérico representa no palco da mestiçagem e da mundialização - fenômenos banalizados pelos chamados processos de globalização -, aproveito, fundamentalmente, a idéia de que a mestiçagem resulta da confluência de temporalidades distintas cuja imbricação não se explica através da metáfora da concatenação, da sucessão ou da substituição inventada pelos evolucionistas, pois o tempo dos vencedores - o tempo dos europeus na conquista da América - não suplanta o dos vencidos - o tempo dos indígenas -.É preciso admitir que essas temporalidades coexistem e não devem ficar sujeitas à ordem imposta por uma concepção linear do tempo. Em outras palavras, é possível trabalhar com o pressuposto de que a complexidade e a mobilidade das misturas, com suas consequientes interpenetrações de temporalidades diferentes, não é, enquanto elemento que evoca a imagem da desordem, algo surpreendente e, mesmo que assim fosse, faz-se mister convir em que da surpresa podem emanar estalos poéticos ou, dito de outra maneira, fulgores de metáforas dialógicas. E, do catálogo, levando em conta a riqueza do material iconográfico aí reunido, utilizo não só informações contextuais, mas também algumas das configurações do universo pictórico criado por Rivera em seu incansável afã de construir imagens mestiças.

No tocante às vivências particulares, lembro que, ao visitar a $22^{\text {a }}$ Bienal de São Paulo, num dia de mormaço insuportável e intensa iluminação, percebi, de repente, que minha curiosidade me arrastava, quase de maneira inconsciente, até a sala em que se expunham alguns quadros de Diego Rivera. Seria injusto dizer que me desinteressava pela produção dos artistas da contemporaneidade. Confesso meu fascínio pela criatividade do trabalho fotográfico apresentado por Rosângela Rennó ou, então, pelas experiências que, com base no 
que poderíamos chamar uma poética da moldura, fazem artistas como Juan Luis Moraza e Igor Kopystiansky, sem esquecer a produção em vídeo de Gary Hill. Mas, sinceramente, eu me sentia carregado para o recinto destinado aos quadros do famoso muralista. Era uma chance única. Conhecia os afrescos do Palácio Nacional, do México, e, por um acaso objetivo, como diriam os surrealistas, tive em mãos um exemplar do Popol-Vuh que a editora Eikichi Hayachiya, com aquarelas do pintor, publicou em 1961.

As ilustrações que o pintor realizou em 1931 foram, certamente, as imagens que desencadearam meu interesse, já que nelas vislumbrava uma espécie de complementação plástica ao indigenismo literário posto em prática por Miguel Angel Asturias, escritor que eu vinha estudando já fazia tempo' e que nos deixou uma tradução memorável do Popol-Vuh (1965) ${ }^{2}$. Essas ilustrações possuem o bizarro encanto de composições cujas formas iconográficas, mesmo sendo estranhas a um olhar moldado nos parâmetros figurativos do

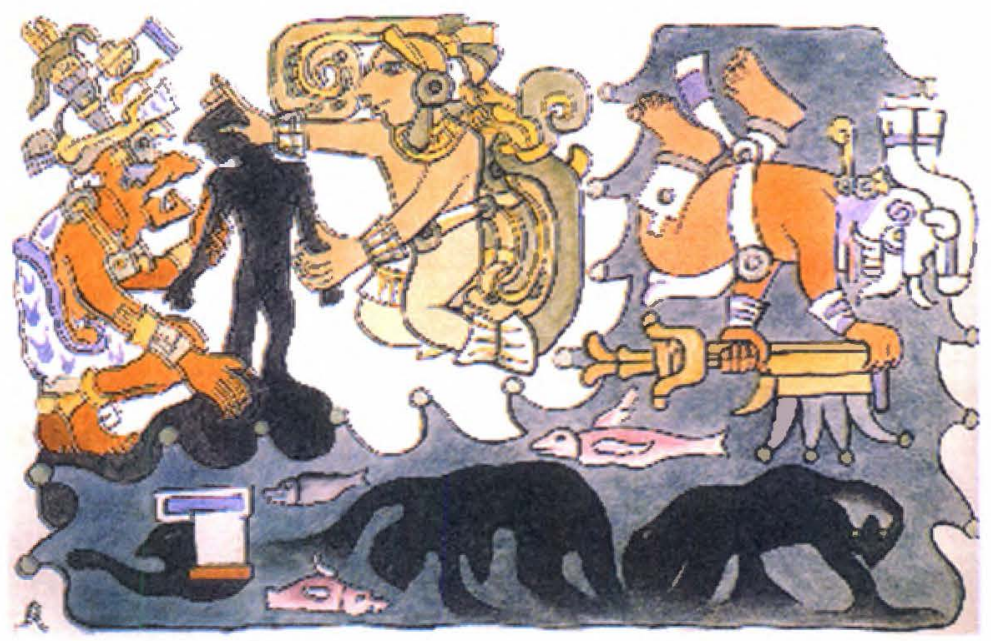

1. Em meu livrinho Duas Leituras Semióticas (1978), um dos ensaios tem como tema o indigenismo no romance El Señor Presidente.

2. Na verdade, a versāo de Asturias, feita em 1927 com a colaboraçāo de González de Mendoza, ê a traduçāo ao castelhano da versão francesa que Georges Raynaud tinha realizado do Popol-Vuh. Mesmo assim, há no texto do escritor guatemalteco uma inconfundivel riqueza expressiva, uma proliferaçăo de metáforas cuja polissemia aproxima o leitor do misterioso universo poético dos indigenas. 
imaginázio ocidental, como se pode constatar na reproduçăo de uma delas que mais adiante transcrevo e que se encontra à página 360 do Catálogo, me colocavam diante de signos plásticos que, apesar de não atinar com seu sentido original, se me afiguravam familiares.

Tal sentimento era fruto de uma leitura das figuras meramente intuitiva, pois, mesmo desconhecendo então os códigos ameríndios manipulados por Diego Rivera em suas aquarelas, entrevia através dos afazeres das personagens representadas nessa ilustração do Popol-Vuh algo dos significados de seus gestos e eles me falavam de deuses atarefados, de bonecos subjugados e, ainda, convivia bem com a percepção de animais que se movimentavam num ambiente indefinido. Mais tarde, quando me lancei à tarefa de estudar os códices, consegui identificar vários dos pictogramas e ideogramas estilizados por Rivera e soube, agora já com certa segurança, que a ilustração acima reproduzida se referia ao episódio em que os deuses formadores destroem os homens feitos de madeira extremamente rígidos e, por isso, portadores de uma insolência ofensiva - e se entregam, depois de um dilúvio catastrófico, ao trabalho de preparar o milho com o qual seria feito um homem novo. A partir daí minha relação com as imagens mestiças começou a se esboçar.

Além do mais, sempre foi grande minha admiração pelas idéias que, sobre o papel da arte na sociedade, Rivera defendeu em várias ocasiões, principalmente por aquelas comprometidas com a proposta de dialogar com o assombroso mundo iconográfico dos povos indígenas da América. Vale dizer, por conseguinte, que a premência de entrar em: contacto direto com algumas obras que eu desconhecia não era, no fundo, efeito de um arrebatamento inconsciente. Existiam, embora de maneira bastante embrionária, motivos que apontavam para as causas da minha curiosidade e hoje, depois da minha recente visita ao México e da obtenção do Catálogo mencionado ${ }^{3}$, esses motivos ganharam consistência, principalmente por estar convencido de que a imagem mestiça no só ocupa um lugar relevante nos textos pictóricos de grande parte da obra de Rjvera, mas tam-

3. A convite da Universidad Autónoma Metropolitana, ministrei, no Centro de la Imagen, primeira quinzena de dezembro de 2001. um seminário avançado sobre La Imagen y sus Posibilidades de Lectura, tendo recebido dos estudantes do curso a gentileza de me obsequiar com o Catálogo. 
bém porque essa imagem adquire, em vários de seus quadros, propriedades muito significativas no tocante à estrutura da metáfora visual e ao papel que esta desempenha nos processos dialógicos em que diferentes temporalidades conquistam o direito à coexistência.

Superada a impaciência vinda da curiosidade, lembro ainda que, naquela ocasião, centrei meu interesse na tela Historia de las religiones $I I I$ e, enquanto ouvia, por parte de outros visitantes, vagos comentários sobre a riqueza cromática e a harmonia da composição, minha imaginação foi adentrando-se num território, apenas entrevisto, de jogos intertextuais que me subjugava. Do impacto desses vislumbres me surgiu, de repente, a idéia de escrever algo, de ordenar, com sossego, as intuições que, diante daquele quadro, tive das camadas de sentido que nele se ocultam, que nele articulam conflitos em que se envolvem visões arraigadas nos sertões da poesia. Nasceume, pois, o compromisso de prender, nas desajeitadas redes da minha escrita, estilhaços do conteúdo de configurações que foram e ainda são incógnitas que protagonizam múltiplos itinerários interpretativos e que, evidentemente, não eram incluídos nos comentários mencionados.

Mais tarde, refeito dos enlevos vividos durante minha visita à Bienal, ao reler algo que eu mesmo tinha escrito sobre as conquistas da leitura, passei a remexer nalgumas das minhas intuiçōes. Gostaria de reaproveitá-las, conferir-lhes outra ordem, pautar-me na ilusão de que, ajeitadas no suporte da palavra, delas poderá, quem sabe, tirar proveito alguém que, com mais ou menos relutância, se renda aos feitiços dos significados que emergem cada vez que, no aperto de um abraço sem fronteiras, objetos de temporalidades e lugares diferentes se interpenetram para manter entre si um diálogo em que vozes mútuas trazem até a percepção do espectador profundas ressonâncias. Ou, quiçá, zumbidos provocados, num texto mestiço, pelas engrenagens temporais. Porque não parece absurdo reconhecer que nas imagens mestiças se misturam diversas maneiras de representar o mundo sensível, diversas maneiras de traduzir, mediante figuras diferentes, imbricadas, porém, numa única estrutura textual, essa pluralidade de pontos de vista de que, em última instância, se alimenta o dialogismo e, conseqüentemente, a coexistência de modos de ver díspares. É por isso, penso eu, que, em qualquer uma 
dessas configurações, os mundos construídos pelo homem se apresentam como imensos museus onde as mais diversas práticas, transformadas em signos, dialogam sem nenhum tipo de constrangimento. Talvez, nesse jardim semiótico, os objetos falem a língua universal de todas as constelações míticas.

Tudo parece indicar que os temas desses insólitos diálogos são balizados pelos valores afetivos que se aderem aos signos quando seu valor de uso se universaliza. O que de maneira mais profunda se manifesta neles provém, considerando a pluralidade dos eixos semânticos postos em jogo, de uma verticalidade de sentido cujos extremos, afetados pelas mediações metafóricas, chegam a se confundir e a superar qualquer tipo de contradição. Fica disso a forte impressão de que a afetividade injetou, na epiderme dos objetos fabricados pelo homem, as irradiações de uma substância movediça cuja constante agitação produz cargas pulsionais que causam, entre outros efeitos, alvoroços nas diferentes matérias formadoras das estruturas significantes - a voz ${ }^{4}$, os gestos, as cores -.

Enquanto prolongação do corpo humano, os objetos desse extraordinário museu exibem, na sua condição de peças que fazem parte de um acervo cultural ou das entranhas de quem usa a imaginação para fixá-las nas paredes da memória, vestígios que remetem a camadas sensíveis anteriores a qualquer ato de linguagem. Nessa perspectiva, o diálogo mantido pelos objetos nasce, enfim, do processo de significação que se instaura a partir do confronto de fenotextos com geno-textos (Kristeva, 1974), confronto em que borbulham traços do pensamento mestiço a que, segundo creio, Gruzinski se refere.

Algo disso devo ter intuído quando, anos atrás, tocado seguramente pelos efeitos de sentido que se deslocam ou se condensam nas camadas mais fundas dos objetos, sejam eles artísticos ou não, reuni estas palavras:

Gosto de me deixar envolver no silêncio dos museus, de percorrer os seus recintos com o intuito de inventar, sempre, a aventura de quem se sonha perdido num emara-

4. Digo a voz porque, no tipo de escrita dos nauas, o rébus amalgama em seu plano expressivg imagens com sonoridades evocadas. 
nhado de corredores cuja arquitetura, apesar dos simulacros labirínticos, lhes traça um mesmo e quase único destino. Gosto, portanto, de me adentrar nesse simbólico mare nostrum feito de paredes com brancura de espumas $e$ onde, à maneira de ilhas solitárias, flutuam objetos que, além de magnetizarem qualquer tipo de miragem, lançam à deriva a suspeita de que foram lá colocados com a exclusiva finalidade de armar, nas pupilas daqueles que os encaram, enigmáticas imagens que ondulam, trêmulas, ao ritmo de um incitante vaivém de distâncias. Gosto, enfim, porque pressinto, enquanto parceiro desse jogo de sutilezas, que, na escuridãoo dos reinos da retina, as imagens se espalham pelos sertões da minha memória e, libertas de normas de trânsito, cada uma, em seu todo ou em suas incontáveis fragmentações, toma comigo o rumo que thes é indicado pelas forças magnéticas implicadas nos chamados processos associativos. (1990, p.64).

Em sua aparente quietude, um simples quadro pode ser motivo suficiente para desencadear associações e, através delas, introduzirse nas figurativizações que propiciam os ingredientes semânticos geradores das condições de coexistência. Fico, pois, com a escolha que fiz naquela oportunidade e peço ao leitor destas linhas que fixe bem seu olhar no quadro que a seguir se reproduz, já que, desse contato emergem várias possibilidades de leitura.

Com o único propósito de recolher amostras que aludem a referentes cujo entorno mítico não cabe já na lógica de nossas cotidianas crenças, recorro, agora, a figuras dessa cartografia deslumbrante que se espalha nos códices indígenas sobreviventes a todo tipo de naufrágios. Dessa perspectiva, diante da particular iconografia de Historia de las Religiones $H H^{5}$, assumo a tarefa de lançar-me à procura de textos da cultura ameríndia com os quais muitas das imagens que compõem essa obra de Rivera dialogam e, para tanto, enfocarei exclusivamente minha atenção nos gestos e geometrias que se agrupam em seu espaço pictórico.

5. Rivera nos deixou várias obras sobre este assunto, sendo, entretanto, Historia de la religión l e Historia de la religión $V$ as que expressam de maneira mais explicita o compromisso do artista com a iconografia ameríndia. 


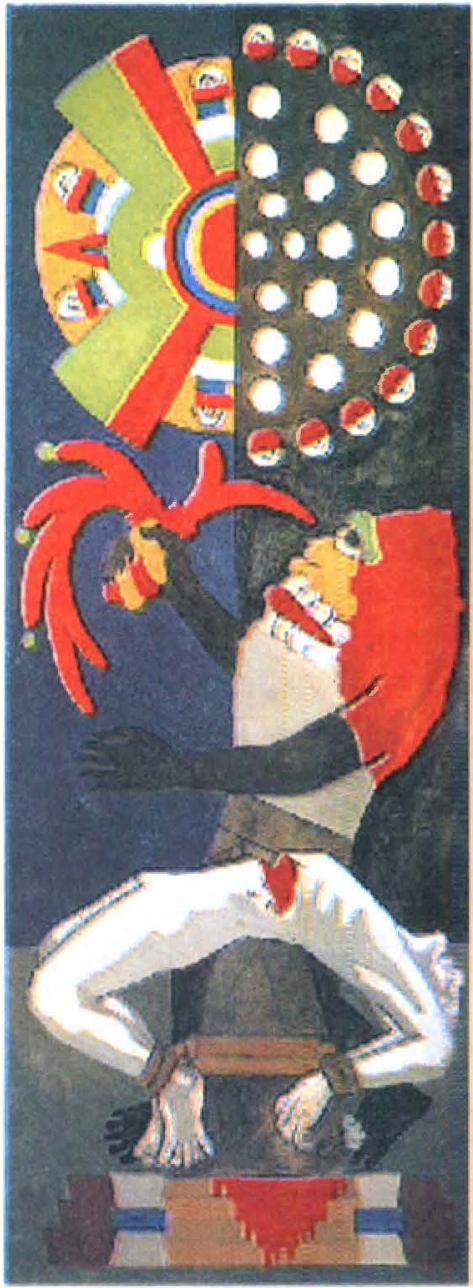

Da gestualidade emanam significados que qualquer espectador atento pode decodificar: uma pers oragem lenebrosa ${ }^{6}$ oferece de maneira taciturna o coração de uma vítima humana que exibe, no topo desse arco tenso em que se trars abertura de uma ferida fatal. Mas, sitnando-se do outro lado do óbvio, o observador desses gestos pode, com auxílio de referências

6. Utilizo este adjetivo para externar, ideolozizamente, $\propto$ s sentimentos de espanto que, em mim, como reminiscência obscuré de atos frrmordiais, permanecem. Sobre esta questāo já se escreveu muito 2 o que desejo destacar aqui é tão somente o compromisso da adjetivaçāo ccrr o simbolismo disfórico que o negror 
mais arraigadas na antropologia, nos relatos dos cronistas e na iconografia indigena, ir além das fronteiras da impressão e, conseqüentemente, conquistar o privilégio de se adentrar nos territórios do simbólico e do obtuso (Barthes, 1986, p. 19). No nível do simbólico, o gesto de levantar o coração permite outras interpretações. Assim, se aproveitarmos as informações que acerca desses ritos fornece Yolotl González Torres em seu livro El Sacrificio Humano entre los Mexicas (1992), constatamos que o sangue, na crença dos indígenas, servia, enquanto líquido precioso, para tornar efetiva a comunicação dos humanos com o mundo sobrenatural. No quadro de Rivera, o sangue jorra, qual líquido transcendental, do coração empunhado pelo sacerdote e ainda mancha de vermelho as escadas do templo em que o sacrifício se realiza, detalhes que traduzem, com minuciosa fidedignidade, os significados que também o antropólogo citado recupera em sua descrição do rito, principalmente quando destaca os valores do tlacamictiliztli (sacrifício humano) e do téchcatl (piso de pedra), cena e cenário, respectivamente, de um ato transcendental.

Em razão de seu caráter pan-cultural, a linguagem gestual oferece menos resistência à interpretação. Seus componentes, icônicos no geral, permitem uma decodificação quase direta, pois o leitor da pintura, mesmo que conheça unicamente os códigos cristalizados pela cultura ocidental, capta, sem maiores problemas, os significados básicos do conjunto de atos que, através de gestos e movimentos congelados, se manifestam no quadro. É possível, entretanto, aprofundar a leitura. Isso pode ser feito, por exemplo, se explorarmos o aspecto emotivo que aparece em determinados lugares do espaço plástico. Os grandes dentes do sacerdote exprimem, pelo tamanho e pela brancura óssea, uma indisfarçável ferocidade, traço que pode ser interpretado com mais precisão se se aprovejtam as particularidades da iconografia dos mistecos.

Nos códices ameríndios, é difícil encontrar gestos em que aflorem as emoções. As personagens são representadas, amiúde, de perfil e o que as identifica não é a feição física. Elas são reconheci-

do sacerdote pintado por Rivera, numa primeira olhada, transmite. Mas o leitor terá oportunidade de constatar que, no transcorrer deste ensaio, minhas impressões văo mudando na medida em que dados propiciados pela intertextualidade situam as imagens da pintura em contextos dominados pelo poético. 
das pelo nome. Nas cenas em que se apresenta o sacrifico de seres humanos se observa, no entanto, uma gestualidade impregnada de emoção. Assim, por exemplo, no Códice Nuttall, fólio 81, a representação pictográfica de um ato de sacrifício flagra o momento exato em que a faca de "pedernal" penetra no peito da vítima e faz jorrar o sangue.

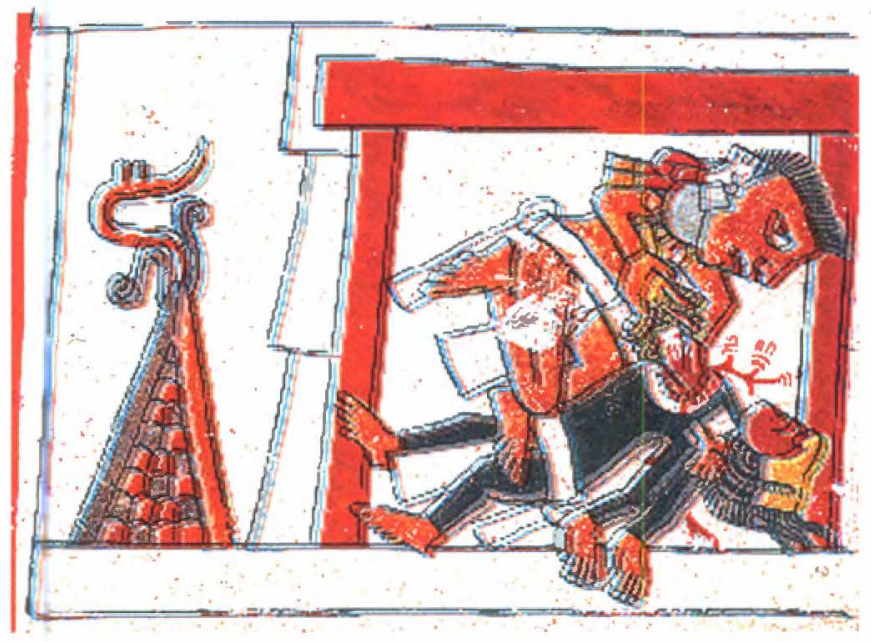

Basta olhar a expressão facial do sacerdote ${ }^{7}$ para perceber nela uma carga de emoção que o tlacuilo ${ }^{8}$ não quis ou não soube evitar. Neste ponto, o quadro de Rivera mostra mais uma vez seu alto grau de comprometimento com certas formas assumidas pela escrita dos ameríndios, principalmente se se pensa que um termo como tlacuiloztli significa tanto escrever quanto pintar. Poder-se-ia, ainda, explorar outros aspectos. A disposição do corpo da vítima ou a forma e local do talho preservam, por exemplo, marcas de uma ostensiva obscenidade, na acepção etimológica do vocábulo. As regras de uma tradição consagrada pelos oficiantes conferem aos gestos significados arraigados numa visão de mundo em que elementos como a chuva e a terra protagonizam as ações de um relato primordial, de uma fábula enigmática utilizada pelos indígenas para dar forma não ezclusivamente ao pensamento mítico, mas, também, ao pen-

\footnotetext{
7. Em seus comentários, Arthur G. Miller (1975, p.11), destaca a emoção facial do sacerdote e da vítima "in such a terrible situation".

8. Termo que, na língua naua, designa o escriba.
} 
samento filosófico e ao conhecimento das relações do movimento dos planetas com o tempo que durava a germinação de um grão de milho. Sangue e chuva significavam sobrevivência, alimento precioso que arranca a morte das garras do nada, tal qual se constata na fábula plasmada nesta reprodução de uma das lâminas do Códice Tudela:

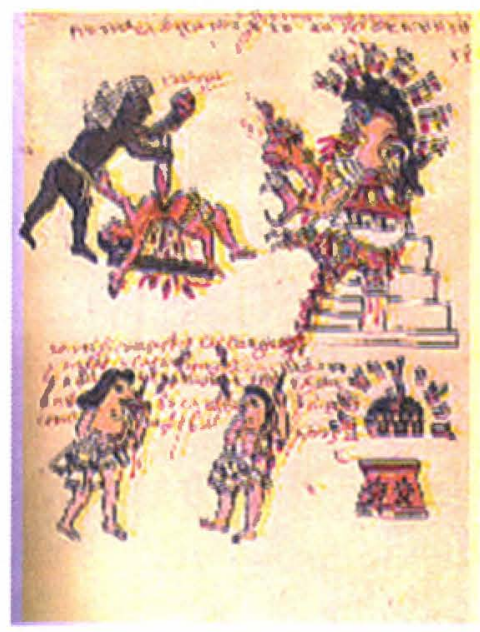

No que tange às geometrias, porém, a tarefa de decifrar requer outros cuidados. Assim, a combinatória dos semicírculos demarca um lugar no espaço da tela cuja leitura, considerando os códigos pertencentes à escrita indígena e os códigos da recepção os que, nesta ocasião, utiliza um receptor educado na rigidez emblemática das conotações atribuídas às formas geométricas pelo pensamento helênico -, depende, em boa parte, da superação de várias etapas. Uma delas, fundamental no caso, diz respeito à relação de intertextualidade que a geometria de Rivera mantém com a escrita pictográfica dos códices mexicanos. Analisar, pois, essa questão abre caminho na direção de nuanças de significação que se localizam nos lugares mais inesperados do texto pictórico do artista mexicano. Além disso, no percurso desse caminho tropeçamos, com frequiência, em metáforas visuais de denso conteúdo poético.

A identificação de grafos e ideogramas facilita a escuta dos diálogos instaurados em muitas obras de Rivera pela presença de imagens mestiças. O Catálogo é pródigo em exemplos, sendo um 
dos mais representativos a representação de Coatlicue que aparece no detalhe do mural El Hombre, Controlador del Universo, reproduzido à página 249. Mas, voltando à tela Historia de las Religiones III, a circularidade resultante da condensação das figuras olhadas pelo sacerdote remete ao encontro de significados que a combinação de elementos de sistemas semióticos diferentes engendra. De um lado, essa circularidade pode representar valores positivos compromissados com a disposição bem ordenada das partes de um todo, com a harmonia das esferas e das alturas, com o mistério, em soma, dos corpos celestes relacionados com deidades, como se observa nas pinturas egípcias ou no conhecido disco solar englobando o rosto de Cristo pintado por Odilon Redon. De outro, as formas conseguidas por Rivera espelham, de maneira mais direta, configurações plasmadas pelos tlacuilos nos "livros pintados". Assim, na página 11 do Códice Borbónico, por exemplo, encontramos uma imagem semelhante.

Aí aparece Pantékatl, com o rosto tingido de duas cores e manchas nas bochechas. Este deus representa a embriaguez de Quetzalcóatl, motivo causador da sua ruína. Entre o nume e seus acompanhantes surge um círculo cujo lado esquerdo simboliza a noite e o direito o dia, pictograma que nos fornece a informação de que esses ritos eram noturnos e diurnos.

O encontro desses dois núcleos de significação na configuração plástica obtida por Rivera encobre, porém, camadas de signifi-

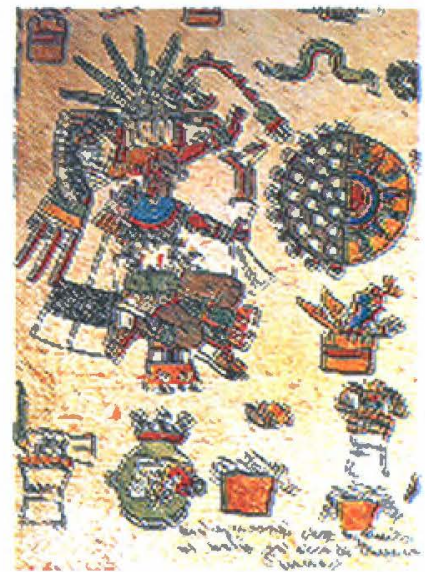


cados mais sutis. Os semicírculos concêntricos inseridos ou dispostos na margem das figuras geométricas da parte superior da tela são grafos e significam luminosidade. No contexto do quadro, contudo, instauram uma rima plástica se lidos através do vínculo formal que eles mantêm com os olhos do oficiante. Mas, em contrapartida, dos valores semânticos que aí se insinuam emerge um tênue contra-senso: a brancura dos semicírculos interiores, ao transmitir a idéia de brilho, contrasta com a mancha ${ }^{9}$ plasmada naquela parte que seriam as pupilas do sacerdote, conotando, na diacronia de uma intertextualidade mais abrangente, além da tenebrosidade ancestral e dos magnetismos sexuais imputados ao negrume, significados que desenterram valores míticos soterrados pelo tempo e, ainda, sentidos obtusos que se depreendem de minúcias tais como as que se manifestam na linha que traça o contorno do nariz e do lábio superior do oficiante.

Em geral, os olhos dos oficiantes que aparecem nos códices não possuem essa característica. São poucos os casos em que a pupila do oficiante, um ponto inteiramente negro, como se pode observar em várias imagens do Códice Bodley publicadas por Alfonso Caso. Aí, năo só o olho do sacerdote aparece sob a forma de uma minúscula mancha negra, mas também o da personagem que, com gesto imperativo, parece estar ordenando o sacrifício de um guerreiro de quem, em virtude do grafo colocado perto de sua cabeça, sabemos o nome: chama-se 8 Veado. De qualquer modo, creio que, entre as coincidências expressivas e os desacordos semânticos da rima assinalada, a significação flutua e espalha ambigüidades acobertadas com uma tessitura de cores. Por isso, mesmo sem esquecer o simbolismo cromático, estou convencido de que o dialogismo textual da tela de Rivera deve ser interpretado com o auxílio das contribuições que possam propiciar outras referências textuais. Assim, no Códice Nuttall, aparece, nesta cena de sacrifício transcrita a seguir, um sacerdote cuja escuridão facial contrasta com a brancura dos círculos que formam os olhos.

9. Embora os olhos do oficiante não sejam, na pintura original, exatamente negros, utilizarei esse termo para traduzir a escuridão que emana do arranjo cromático empregado pelo artista para ressaltar a força do olhar do sacerdote. Por questôes de simplicidade, utilizarei também o nome pupila sem me preocupar com o rigor de uma denominação correta em termos anatômicos. 


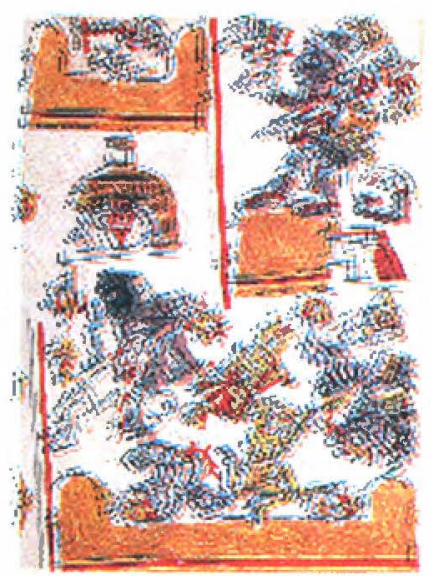

Segundo a leitura feita deste fragmento pelos investigadores Ferdinand Anders, Maarten Jansen e Gabina Aurora Pérez Jiménez (1992, p. 220), a cena representa um vale entre duas montanhas onde lutam guerreiros- guias e guerreiros-jaguares, mais precisamente o momento em que o sacerdote naual Serpente de Fogo voa empunhando o coração arrancado de um guerreiro tigre e o Senhor 9 Flor, conforme nos diz o glifo colocado na sua frente, abre, com sua faca de obsidiana, o peito do vencido, cujo corpo, por sinal, foi desenhado numa posição semelhante à que pinta Rivera em seu quadro.

De acordo com os grafos situados na parte superior direita, bem encima do guia, a cena se deu no ano 8 Coelho e no dia 10 Coelho, isto é, em 1.098 de nossa era. De posse dessas informações, emociona pensar que as figuras plasmadas pelo tlacuilo se reportam a um fato tão distante, a peripécias repetidas com tanta teimosia pelos homens em suas persistentes tentativas de encontrar respostas para as muitas incógnitas da vida. Esse negrume do rosto do Senhor 9 Flor, lido hoje, se impregna, pois, de um simbolismo disfórico com o qual, creio, dialoga o negror e a pupila negra do oficiante pintado por Rivera ${ }^{10}$.

10. Convém lembrar que termos como macabro e horripilante nāo aparecem só nos textos dos cronistas destinados à descrição dos sacrifícios ou à aparência das divindades da morte, mas também nos textos dos antropólogos da atualidade, mesmo quando neles se procura compreender mais do que condenar. A idéia de monstruosidade engloba, às vezes de maneira disfarçada, esses significados, como se pode constatar, por exemplo, na descrição, aparentemente fria, que Jil Leslie Furst e Peter T. Furst fazem em L'Art Précolombien du Méxique (1982, p.118). 


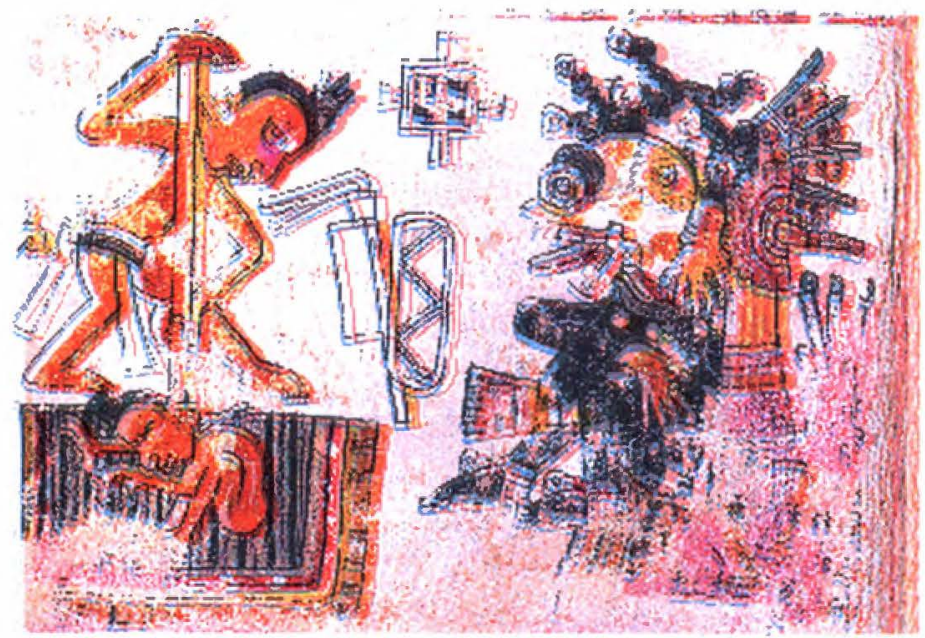

Mais precisamente, com essa negridão funesta que envolve a figura do deus da Morte tal qual ele se apresenta, reprodução acima, em cerimônias como a que o Códice Borgia, na parte inferior do fólio 70, ilustra. O padroeiro desse ritual é o deus da morte, carregando a bandeira branca do sacrifício e entoando cantos fúnebres.

Mas aquilo que me parece ser mais relevante para estas anotações provém do fato de que, no diálogo que a tela de Rivera mantém com a iconografia indígena, se alarga a opacidade detentora, segundo os sabidos conceitos de Jakobson, do potencial poético de uma obra. Enfocado dessa perspectiva, o dialogismo textual produz, em termos significantes, um tipo de opacidade movediça em que os componentes expressivos se refazem cada vez que, na leitura, intervêm diferenças paradigmáticas determinadas pelo constante dinamismo das relações intertextuais, pois, mesmo em configurações visuais que se apresentam como coisa única e estável, a mobilidade marca de vários modos a sua presença. Basta lembrar o que se entende por busca visual e por dupla realidade da imagem para se ter disso uma comprovação convincente. Quanto à busca visual é suficiente recordar que o olhar de um geólogo, de um poeta ou de um antropólogo não é o mesmo e, no atinente à dupla realidade da imagem, cabe assinalar que a imagem representada sobre uma folha de papel oferece à vista figuras que percebemos como fragmentos de uma superfície e como fragmentos de um espaço tridimensional. 
Assim, no caso específico do possível vínculo do oficiante pintado por Rivera com o Mitlantecuhtli plasmado pelo tlacuilo no fólio 70 do Códice Borgia, a opacidade movediça surge no instante em que as configuraçōes relacionadas permitem, em razão das coincidências expressivas das figuras em questão, montar hiper-imagens " cujas significaçōes dependem, em última instância, dos efeitos de semiose gerados pelos processos intertextuais propriamente ditos.

A relação da figura do oficiante de Rivera com o Mitlantecuhtli do Códice projeta, no plano do conteúdo da hiperimagem formada pela combinatória dos componentes dessa parte dos dois textos, intrincados jogos ideológicos que, sobre a morte, montam as religiões, entendidas, em traços gerais, como crenças que se vineulam a uma das dimensões tímicas mais arcaicas do ser humano. Isso quer dizer, entre outras coisas, que, na negridão do sacerdote e na caveira da deidade se amalgama o primitivismo das emoções com a isotopia semântica da religião sugerida pelo título dado ao quadro.

A zaveira, enquanto símbolo da morte, foi, como já mostraram os principais estudiosos das culturas mesoamericanas, uma das formas ornamentais mais populares. $O$ fato de que ela ainda hoje continue sendo enfeite dos mais diversos objetos usados nos afaze res da vida cotidiana constitui prova evidente da persistência de seus valores simbólicos. Sabe-se que para celebrar o ciclo de 52 anos, fim de uma época passada em certos calendários ameríndios e começo de um tempo novo, era colocada, no templo maior de Tenochtlitan, uma lápida com quatro rostos em que estavam esculpidos ossos humanos e caveiras. Para os astecas, como já se disse muitas vezes, a morte era um parente próximo e, embora pareça paradoxal, a caveira que abrolha no centro da estátua de Coatlicue significa, também, vida. Mas, por outro lado, temos de admitir que, na visão atual do Códice Borgia, as significaçōes positivas da caveira estão contami-

11. Utilizo este termo para me referir à configuração que resulta da sobre-impressão de imagens determinada pelas relaçōes intertextuais. Alguém pode pensar que tal cor figuraçāo tem caràter meramente psicológico. Creio, porem, que tal idéia carece de consistència, pois a hiper-imagem, à vista dos novos recursos tecnológicos, pode muito bem ser representada de maneira objetiva. Exemplo já clássico dessa objetividade é a hiper-imagem conseguida pela combinaçāo do retrato de Monna Lisa com o auto-retrato de Leonardo da Vinci. 
nadas, de certa maneira, por irradiações históricas desse espanto que os cronistas deixaram em suas minuciosas descrições dos sacrifícios feitos pelos índios. Mesmo assim, há passagens dos cronistas em que se vislumbram lampejos das idéias com que os homens renascentistas queriam afugentar os temores da morte, dessa morte que a Idade Média relaciona com as penas infernais e aparece nas Danças Macabras através de formas horrendas.

Mesmo sendo fiel à iconografia indígena, a encenação das imagens do quadro de Rivera conduz a uma primeira camada de conteúdo em que traços marcantes do sincretismo religioso, de supertições e crenças cristalizaram aspectos fundamentais da identidade dos povos latino-americanos. No Códice Magliabechiano, que, como se sabe, foi pintado por volta de 1550 , encontramos, à página 79 , uma deidade da morte muito semelhante à pintada no Códice Borgia: caveira policromada, olhos formados por círculos concêntricos e dentadura agressiva. As principais diferenças residem nas mãos que simulam garras de tigre e no cinto que cai sobre as escadas do templo em que o deus está sentado e se prolonga em forma de serpente imitando um rabo diabólico. Essa mestiçagem de formas pertencentes a sistemas culturais diferentes gera desconcertos e faz com que o leitor oscile entre mais de uma interpretação. Mas as hjper-imagens, enquanto componentes expressivos produtores, por sua vez, de significados mais singularizados, podem colocar o leitor atento no rumo de estratos de sentido mais profundos, mais ancestrais e, por isso mesmo, menos comprometidos, no caso, com as contaminações ocorridas no período colonial. Às vezes, sob a aparente originalidade plástica de algumas das figuras que compõem o quadro de Rivera, as relações intertextuais se camuflam com aprimorado requinte.

Destaco; para me deter numa dessas possibilidades, a rima que se estabelece, no plano da expressão, entre a forma da ferida no peito da vítima e a figura do oficiante. Deixando de lado o tamanho de cada uma dessas imagens, ambas, porém, possuem em comum um formato triangular, um formato alongado semelhante ao das facas de obsidiana usadas neste tipo de ritual. Como já disse, a fenda aberta no corpo do homem sacrificado se assemelha à forma do instrumento utilizado no sacrifício. $O$ talho foi pintado de tal jeito que, 
mesmo estando ausente, a arma utilizada para fazer o corte prolongá nele a sua presença. Como complementando essa isotopia, a figura do oficiante, vistá numa relação intertextual mais precisa, lembra, pela sua extraordinária semelhança formal, o teocpatl, uma faca ritual antropomórfica da qual se oferece abaixo uma imagem ilustrativa. As coincidências entre a figura do sacerdote, tal qual foi pintada por Rivera, e a forma deste instrumento são impressionantes. É como se o contorno, os dentes e os olhos tivessem sido arrancados do teocpatl para incrustar no espaço do quadro a ordem e o sentido que eles possuem no objeto original.

A hiper-imagem que resulta desses ajustes intertextuais atesta um tipo de construção cujo grau de mestiçagem parece haver sido gerado por uma força que nasce nas entranhas do artista disposto a anular a distância entre seu texto plástico e o texto do outro. Esta hiper-imagem de Rivera expressa os efeitos de uma pulsão de morte destinada a evocar, segundo o pensamento freudiano, o desejo humano de retorno ao espaço cósmico com o qual sabe que viveu, num tempo que não cabe nos calendários, totalmente integrado. Há, enfim, na metáfora forjada por Rivera uma pulsão desse tipo, só que canalizada na direção de integrar sua leitura plástica com as formas e os conteúdos que assume o cosmos nas mais autênticas iconografias ameríndias.

Em suma, a imagem mestiça, considerada a partir das características apontadas, apresenta uma forma expressiva em que os componentes plásticos se articulam de maneira a anular as diferenças entre figura e fundo, embora esses dois componentes, pelo fato

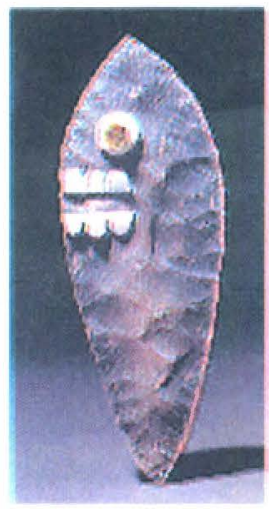


de remanescer, de algum modo, no significante visual propriamente dito, mimam, sutilmente, a questão da coexistência de temporalidades diferentes e plasmam um protótipo plástico adequado à manifestação condensada de diversas confluências cronotópicas. Em consequiência, essa matriz expressiva não só prepara o terreno para uma espécie de pregnância dialógica, mas introduz no plano do conteúdo significados que se atrelam ao eixo semântico da coexistência. Sendo assim, parece-me legítimo extrair dessas particularidades o princípio de que a imagem mestiça, vista ma condição de efeito do inconsciente óptico (Krauss, 1997), não pode ser explicada, como acertadamente defende Gruzinski, a partir de uma visão evolucionista. Vale dizer, por conseguinte, que, se atribuímos à imagem mestiça do quadro de Rivera um valor paradigmático, várias das obras do famoso muralista mexicano reproduzidas no Catálogo já mencionado não devem ser simplesmente lidas em função de serem reflexos de um contex to histórico. Tal leitura, frequiente nos estudos dedicados à pintura deste artista, conduz, lamentavelmente, ao esvaziamento do poder mediador desse tipo de imagem, ao enfraquecimento da carga de transcendência e originalidade que nelas se instala.

\section{Bibliografia}

ANDERS, Ferdinand, JANSEN, Maarten e GARCÍA, Luis Reyes. 1991.El libro del Ciuacoatl. Homenaje para el año del Fuego Nuevo. Libro Explicativo del llamado Códice Borbónico. Madrid/México: Sociedad Estatal Quinto Centenario/Fondo de Cultura Económica.

1992. Crónica Mixteca. El rey 8 Venado, Garra de Jaguar, y la dinastía de Teozacualco-Zaachila. Códice ZoucheNuttall. Madrid/México: Sociedad Estatal Quinto Centenario/ Fondo de Cultura Económica.

1993. Los Templos del Cielo y de la Oscuridad. Códice Borgia. Madrid/México, Sociedad Estatal Quinto Centenario/ Fondo de Cultura Económica.

ANÔNIMO. 1961. Popol-Vuh. Tóquio: Eitora Eikichi Hayachiya. ANÔNIMO. 1965. Popol-Vuh. (Traducción de Miguel Ángel 
Asturias/ J.M. González de Mendoza). Buenos Aires: Editorial Losada. $8^{\mathrm{a}}$ ed.

BARTHES, Roland. 1986. El tercer sentido. Lo obvio y lo obtuso. Barcelona: Piados.

CANCLINI, Néstor García. 1997. Culturas Hibridas. Săo Paulo: Edusp.

FLOCH, Jean-Marie.1985. Petites Mythologies de l'oeil et de l'esprit. Paris-Amsterdam: Éditions Hadès-Benjamin.

FURST, Jill Leslie e FURTS, Peter T. 1982. L'Art Précolombien du Méxique. Paris: Bibliothèque des Arts.

GONZÁLEZ, Maria Ángeles (coord.) 2000. Diego Rivera. Arte y Revoiución. México: INBA/Lunducci Editores.

GONZÁLEZ TORRES, Yolotl. 1992. El Sacrificio Humano entre los Mexicas. México: F.C.E.

GREIMAS, A.J. 1979. Sémiotique. Dictionnaire raisonné de la théore du langage. Paris: Hachette.

GRUZINSKI, Serge.1999. La pensée métisse. Paris: Fayard.

KRALSS, Rosalind E. 1997, El inconsciente óptico. Madrid: Tecnos.

KRISTEVA, Julia. 1974. La Revolution du Langage Poétique. Paris: Seuil.

MILLER, Arthur G. 1975. "Introduction to the Dover edition". The Codex Nuttall. New York: Dover Publications, Inc.

PEÑUELA CAÑIZAL, Eduardo. 1977. Duas Leituras Semióticas. São Paulo: Perspectiva.

. 1991. As fascinantes conquistas da leitura. O Ensino da Arte e sua História. São Paulo: MAC-USP.

ZAVALA, Iris M. 1991. La posmodernidad y Mijail Bajtín. Madrid: Espasa-Calpe. 